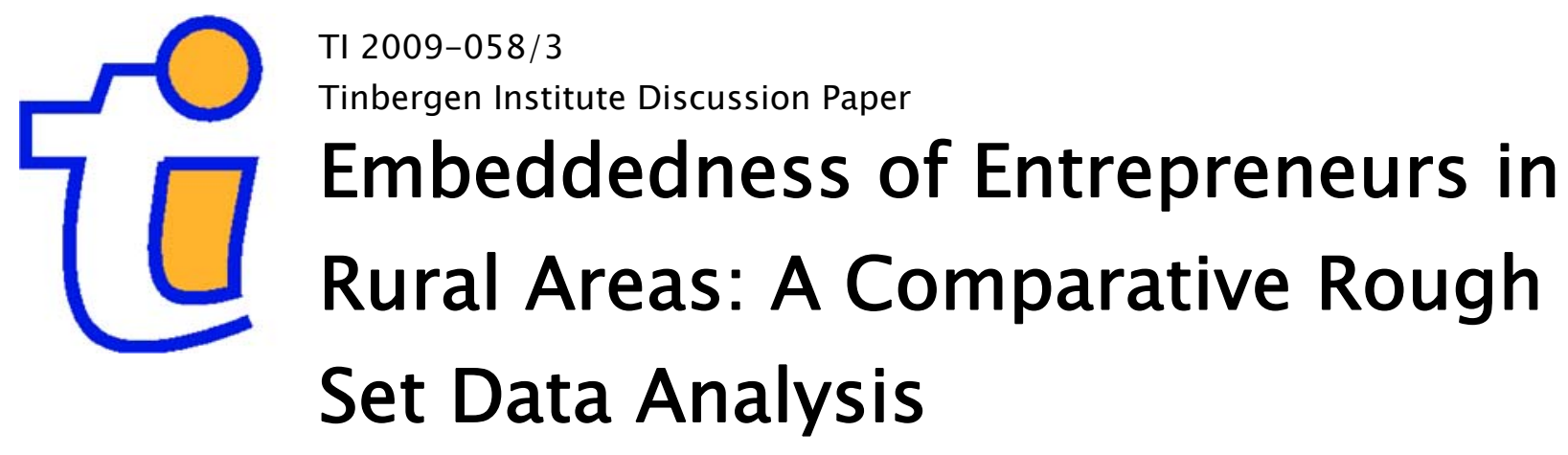

\author{
Aliye Ahu Gülümserl,2 \\ Peter Nijkamp ${ }^{1,3}$ \\ Tüzin Baycan-Levent ${ }^{2}$ \\ Martijn Brons ${ }^{1}$
}

\footnotetext{
' VU University Amsterdam;

2 Istanbul Technical University;

3 Tinbergen Institute.
} 


\section{Tinbergen Institute}

The Tinbergen Institute is the institute for economic research of the Erasmus Universiteit Rotterdam, Universiteit van Amsterdam, and Vrije Universiteit Amsterdam.

Tinbergen Institute Amsterdam

Roetersstraat 31

1018 WB Amsterdam

The Netherlands

Tel.: +31(0)205513500

Fax: $+31(0) 205513555$

Tinbergen Institute Rotterdam

Burg. Oudlaan 50

3062 PA Rotterdam

The Netherlands

Tel.: + $31(0) 104088900$

Fax: $+31(0) 104089031$

Most TI discussion papers can be downloaded at http://www.tinbergen.nl. 


\title{
Embeddedness of Entrepreneurs in Rural Areas: A Comparative Rough Set Data Analysis
}

\author{
Aliye Ahu GÜLÜMSER ${ }^{*}$ \\ Department of Spatial Economics, VU University Amsterdam \\ Department of Urban and Regional Planning, Istanbul Technical University \\ agulumser@feweb.vu.nl; gulumser@itu.edu.tr \\ Peter NIJKAMP \\ Department of Spatial Economics, VU University Amsterdam \\ pnijkamp@feweb.vu.nl

\section{Tüzin BAYCAN-LEVENT} \\ Department of Urban and Regional Planning, Istanbul Technical University \\ tuzin.baycanlevent@itu.edu.tr

\section{Martijn BRONS} \\ Department of Spatial Economics, VU University Amsterdam \\ mbrons@feweb.vu.nl
}

\begin{abstract}
This study aims to identify the critical factor(s) that determine the embeddedness level (EL) of rural entrepreneurs. In order to achieve this aim, existing applied studies on the embeddedness of entrepreneurs undertaken in different rural areas were systematically collected to create a database in order to provide the material for a systematic comparative analysis. This was done in order to highlight common and contrasting findings from a set of selected studies for different ELs. As many results of these studies were largely qualitative in nature and only partially comparable, a specific tool for analysing categorical data based on artificial intelligence methods, viz. rough set data analysis (RSDA), was employed. This experimental study is the first RSDA approach that compares the results of several rural case studies and infers general induction rules for the different ELs. The results of our analysis show that using and benefiting from local resources are the key factors that explain how entrepreneurs become embedded in rural areas.
\end{abstract}

Keywords: rural development, rural entrepreneurship, embeddedness, rough set data analysis Acknowledgement: The authors would like to thank Henri de Groot and Andrea Caragliu for their useful comments.

\footnotetext{
${ }^{*}$ Corresponding author
} 


\section{The position of entrepreneurs in rural areas}

In modern economic theories, entrepreneurship is seen as the main tool to generate change whereby sustainable economic development will be obtained. Although this view is often geared towards urban areas, nowadays entrepreneurship is also seen as a powerful engine for sustainable rural development. Hence, entrepreneurial activities in rural areas feature recently high on the policy agenda. Despite the long history of entrepreneurship studies, rural entrepreneurship did not have a prominent place in the literature until the 1980s (Wortman, 1990). Generally, rural entrepreneurs are defined or studied in the same way as their urban counterparts with reference to their entrepreneurial profiles and their needs, viz. personal motivation, social environment, risk attitude, external business culture and creative milieu. Clearly, in the recent rural entrepreneurship literature, the apparent differences between the milieu created by rural areas and what urban areas offer in terms of social relations - and the specific effects of these relations on economic life - have articulated the need for specific entrepreneurship research.

The idea to regard entrepreneurship as the key issue of rural development originates from endogenous development theory. The rural milieu with all its existing socio-economic potential is increasingly seen as a promising entrepreneurial milieu (Stathopoulou, 2004). To this end, the endogenous potential of both the environment and entrepreneurship needs to be stimulated and supported from within the rural area itself instead of from outside (Petrin and Gannon, 1991), in order to achieve the aim of opening rural systems to the global arena. That is, rural development requires to be induced mainly by local impulses and needs to be grounded largely on local resources. Some of the early attempts to provide short-term local solutions failed mainly because of the inability to create new income resources. This happened because these initiatives were mainly based on the industrialization of agriculture, and innovation had been brought only as an external force into the agriculture sector (van der Ploeg and Saccomandi, 1995). Therefore, this approach may be seen as a failure in terms of answering the needs of the local inhabitants. What was missing was that rural employment was in fact no longer dominated by agriculture (Ilbery, 1998). This meant that rural life called for new challenges to create endogenous growth and development. And therefore, creative entrepreneurship was seen as a new challenge through which the necessary diversification of activities could be obtained.

In the literature, various types of relations, e.g., cultural relations, offered by the rural environment are identified as critical success factors for a variety of new activities created by 
entrepreneurship (Camagni, 1991). The diversity of relations in rural areas and, the needs of entrepreneurs require strong ties in order to obtain successful and sustainable development in the local environment. Schumpeter $(1934 ; 1950)$ argues that what entrepreneurs are doing by being involved in new system-networks is destroying the existing networks. On the other hand, according to Jack and Anderson (2002), the involvement of entrepreneurs in a social context forms a new structure or network according to whether they are contributing or destroying. They explain this new formation by Giddens's structuration theory which can be seen as a parallel to Schumpeter's view of entrepreneurs. In this spirit, maybe not destroying but also contributing, new agents like entrepreneurs have brought innovation, which can be either the creation of external links or a new product, into rural areas. In addition, rural areas also offer newness to entrepreneurs in terms of their local resources or relations, what is called here 'locality'. The condition for what is new and unusual in the market, with the ability to meet demand, enables entrepreneurs to easily benefit and use these resources to start up and succeed.

Rural development on the basis of entrepreneurship aims to achieve the optimum use of local resources while developing and maintaining strong local and external ties among agents ('social capital'). In the literature, the conceptual and operational approach to identify the nature, depth and extent of an entrepreneur's tie to a rural location is called 'embeddedness'. Embeddedness is widely used in the literature and is related to a variety of local network constellations. Generally, it is regarded as a local, informally organized interaction among agents which generally promotes endogenous development (Floysand and Sjoholt, 2007). The embeddedness literature in rural studies has often focussed on the social components of economic action, particularly networks of exchange (Murdoch et al., 2000). In this vein, it has recently been adopted as a conceptual tool to investigate food networks in rural areas (Hinrichs, 2000; Penker, 2006; Sonnino, 2007). Embeddedness is not only used in specific sector studies, but also in entrepreneurship studies: first in immigrant/ethnic entrepreneurship studies in the form of mixed embeddedness (Kloosterman et al., 1999), and more recently in rural entrepreneurship studies. In general, in the literature, its definition is based on linkages to the market and inter-firm networks (Uzzi, 1997), while creating trust between producers and customers, but in the rural literature it is also related to being part of the rural environment in both social and economic contexts as well as to the characteristics of the entrepreneurs.

The present study aims to identify the most important factors that determine the embeddedness level (EL) of rural entrepreneurs, on the basis of a systematic comparative analysis of 
empirical studies on rural entrepreneurship. To achieve this aim, existing applied studies have been systematically collected to form a database in order to provide systematic information for a comparative approach. Our analysis considers variations in terms of sample size, year of publication, and domain of the literature, which all explain the embeddedness of entrepreneurs in rural areas, as well as the specific sector of the enterprise, the origin and gender of the entrepreneurs, and their level of local knowledge, including the external and local strength of their ties. Our database comprises a broad collection of applied studies on the embeddedness phenomenon of entrepreneurs undertaken in rural areas in different parts of the world. This is done in order to highlight common and contrasting findings of selected studies for different levels of embeddedness. As many studies were largely qualitative in nature and only partially comparable, a particular tool for analysing categorical data based on artificial intelligence methods, viz. rough set data analysis, is employed. Although there are many rough set data analysis studies on agriculture and environmental issues, this study is the first attempt to combine the results of rural case studies and to infer general specific induction rules for different levels of embeddedness of entrepreneurs. Section 2 of our paper offers further insight into the ties of entrepreneurs in rural areas, focusing on the concept of embeddedness. Next, Section 3 explores the empirical literature and creates the data set used in this study, while presenting the findings of the analysis. The study concludes by outlining promising future research directions.

\section{Tying entrepreneurs to the local environment}

Entrepreneurship is seen as a requisite for local development (Coffey and Polese, 1984). The main strategies of rural development plans are: securing growth, turning local potential into actual strengths, and achieving expansion beyond rural areas. A number of empirical studies have already demonstrated the success of these strategies. However, these established plans have played havoc with post-war agricultural productivism and rural areas experienced a long period of uncertainty and restructuring (Ilbery, 1998). Restructuration of the main economic activity - agriculture - in order to adjust to national and international processes has reduced the dominant productivist culture. This adjustment often takes the form of generating new sources of income from non-agricultural activities, either on- or off-farm (Bateman and Ray, 1994; Ilbery et al., 1996). However, it may also involve the re-localization of the agro-food system, whereby the original products are transferred to regional and national markets (Marsden, 1996). Indeed, rural areas are becoming important elements of international economic arenas 
and among leading investment frontiers (Clout, 1993). Thus, these transformations, mainly economic ones, have led rural entrepreneurs to think locally but act globally.

Granovetter (1985) has claimed that often desired social and economic outcomes are achieved through embeddedness, based on the interaction between social, economic, physical and environmental conditions. 'Embeddedness' is a notion developed by economic sociologists to emphasize the social dimension of economic activities. The term 'embeddedness' is widely used in the literature in relation to many socio-economic developments. The concept arose from Granovetter's (1985) interpretation and extension of the earlier ideas of Polanyi (1944). According to Granovetter (1985), economic activities need social relations. He argued that social relations have an important and significant role in terms of generating trust for economic activities to happen. From this perspective, entrepreneurs in rural areas should preferably achieve embeddedness in order to start-up, survive, and succeed in their businesses. However, because of the heavy dependency of rural inhabitants on primary group relationships and close personal ties (Frazier and Niehm, 2004), becoming embedded is not an easy task for entrepreneurs. In rural areas, there exists often a very defensive localism (Winter, 2003) in terms of accepting the new. Therefore, it is important that the local community including agricultural labour is engaged in new enterprises (Roberts, 2002). Otherwise, this closed social and economic system can negatively affect entrepreneurship and also be affected negatively by it.

Entrepreneurs rely particularly on local information and resources in the process of business venturing (Romanelli and Schoonhoven, 2000). Entrepreneurship, which is seen as a locally-based economic system, is tied to the collective efforts of members of communities (Flora et al., 1992; Kinsley, 1997; Miller and Besser, 2000). Rural areas are basically social systems where social networks and ties are more important than any other relations. Therefore, the ties between entrepreneurs and rural areas require local potential to link production to consumption. On the other hand, business needs a market area in order to be present and survive. On this basis, it is plausible to say that rural entrepreneurs, depending on their entrepreneurial characteristics, are increasingly choosing rural areas as a living and working environment or as a resource/input of their entrepreneurial process, while seeing the market as a must for their business (Figure 1). Thus, rural entrepreneurs must have ties with both areas: rural and market. Therefore, the link between production (local resources) and consumption (market beyond rural areas) needs to be developed. In addition, the embeddedness of entrepreneurs creates a new rural area which is a new socio-economic system, whole parts of which 
benefit. In other words, the embeddedness of entrepreneurs in rural areas brings: first, knowledge to rural areas about the market and beyond, which is a new system; second, innovation to the market, as rural areas are not very well known in the market as a resource; and finally, an environment to the entrepreneur who is striving, according to his/her own needs, to have a better living.

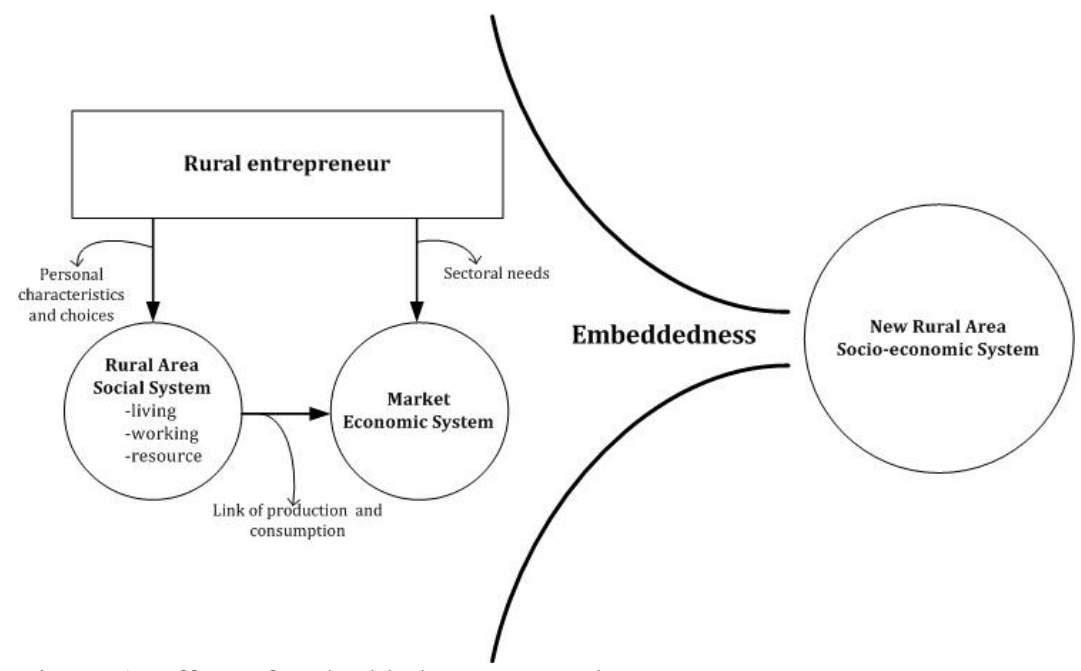

Figure 1. Effect of embeddedness on rural areas

Embeddedness, broadly interpreted as the nature, depth and extent of an agent's ties with the environment, has more recently been conceived of as a configuration element of the general business process (Dacin et al., 1999; Jack and Anderson, 2002; Uzzi, 1997; Whittington, 1992). Embeddedness emphasizes the importance of, on the one hand, social relations in generating trust and discouraging opportunism, and on the other, the linkages that an enterprise forms with a network of enterprises within the region (van Leeuwen and Nijkamp, 2006). Therefore, in the literature, major types of embeddedness differ with respect to the relationships of producers - entrepreneurs - with the market and customers, including those with the geographical, social or sometimes natural assets of their location. Consequently, embeddedness is evaluated not only as the social component of economic activity but also as the key indicator in order to use at least one of the local assets. Thus, different types of embeddedness cover local embeddedness (Kalantaridis and Bika, 2006b), social embeddedness (Uzzi, 1999), ecological embeddedness (Penker, 2006; Whiteman and Cooper, 2000), and spatial embeddedness (Sonnino, 2007). Most of the cited embeddedness studies evaluate the integration of the economic partner into the social network by gaining the trust of society. Therefore, Kloosterman et al. (1999) evaluated embeddedness as a two-sided tie of both the economic partner and the social partner, and called this type of embeddedness 'mixed embeddedness'. 
The common finding from all the studies is that the embeddedness of entrepreneurs in both local and beyond local settings, i.e. the presence of other entrepreneurs and individuals from outside of their environment, is very important if entrepreneurs are to succeed. On this basis, being embedded in rural life will create opportunities and resources if local assets are used, while being embedded in the outside will create a new market and more customers. Thus, both these directions of embeddedness will stimulate the success of entrepreneurs and will definitely affect rural areas. Developed local resources and the dependency of life on social assets in rural areas particularly emphasize the importance and necessity of embeddedness as a mutual benefit mechanism.

In rural entrepreneurship studies, embeddedness is measured by the locality and externality of entrepreneurs' market and social relations, including the involvement of rurality in the entrepreneurial process. In other words, locality measures whether entrepreneurs have local relations in terms of production from and for locals, while external relations emphasize production from or for outside rural areas. In addition, rurality shows the extent to which rural resources, i.e. environment and labour, are added to their entrepreneurial process. Based on the literature in our sample, different dimensions of embeddedness in terms of this multidimensional structure can be grouped into four categories:

1. Disembeddedness: refers to entrepreneurs who have no economic or social relations with the local environment but produce and sell outside of the rural area;

2. Underembeddedness: refers to entrepreneurs who have not yet gained full trust but are trying to have the local community as their market in order to sell their products;

3. Embeddedness: refers to entrepreneurs who have obtained a balanced and integrated relationship pattern between themselves and society in the local area.

4. Overembeddedness: refers to entrepreneurs whose innovativeness is barred by social closure, and therefore their creativity has led them to create external relations by protecting their embeddedness in order to expand their business.

The increasing attractiveness of rural areas has affected the emergence of small firms, while influencing entrepreneurs' and their behaviour (Keeble and Tyler, 1995). Therefore, significant aspects of what entrepreneurs need for business start-ups in rural areas differ from their urban counterparts. In other words, maleness, higher education and entrepreneurial parents are not as fundamental for business start-ups in rural areas as they are in urban areas (Weber, 2007). In urban settings, the entrepreneurs are heterogeneous and have a low involvement in social networks (Renzulli et al., 2000). 
In contrast, in rural areas entrepreneur are more homogenous and have an involvement in social groups (Francis et al., 1990). Moreover, rural entrepreneurship studies focusing on embeddedness stress gender, the use of local resources, the origin of entrepreneurs, and the sector in which they are operating. Rural areas are not seen as declining or problematic, but rather as growing and dynamic. Having entrepreneurship at the heart of sustainable rural development means to optimize the use of the indigenous resources and opportunities of the rural area and transfer them into the global competitive arena as outputs. On this basis, it is important that entrepreneurs know what the local community needs and what the local community has, while being able to act globally.

\section{Embeddedness of rural entrepreneurs: a comparative study of the empirical data}

Rural studies including rural entrepreneurship studies are mainly based on individual cases rather than large-scale surveys. Thus, rural entrepreneurship studies cover usually qualitative studies or partially quantitative studies. This limits the quantitative generalization of the overall results for the population, as qualitative small-scale studies reflect only the behaviour of the sample. While drawing attention to this gap in the literature, we are in this study aiming to find common and contrasting outcomes of studies of embeddedness in rural areas.

The difficulty of working with large samples in rural areas has led researchers to use small and focused samples and to undertake semi-quantitative or qualitative studies. The need to combine the results of several studies which address the embeddedness of rural entrepreneurs led us to use a systematic comparative approach to produce a more accurate set of results in order to accumulate existing knowledge about the topic. However, the embeddedness of entrepreneurs is the subject of many fields, e.g. ethnic entrepreneurship, food sector management, etc., and the embeddedness of rural entrepreneurs has recently been studied under a number of different assumptions usually as a means to examine the nature of rural entrepreneurs.

Taking all this into account, on the basis of the qualitative structure and characteristics of several empirical studies on rural entrepreneurship, in this present study, in order to compare the results of different studies, we used rough set data analysis (RSDA). In principle, RSDA is a non-parametric classification technique (Nijkamp and Rietveld, 1999) which has been developed as an artificial intelligence method for the multidimensional classification of categorical data by Pawlak (1991) and Slowinski (1992). RSDA serves to pinpoint regularities in classified data, in order to identify the 
relative importance of some specific data attributes and to eliminate less relevant ones, and to discover possible cause-effect relationships by logical deterministic inference rules (van den Bergh et al., 1997). RSDA is able to handle any measurement level of relevant variables ranging from cardinal to categorical. It aims to identify the causal conditions (if... then...), under which statements on 'cause' variables can be made in relation to 'effect' variables. In this sense, it may be regarded as a qualitative regression analysis. For more details we refer to the above-mentioned publications.

In this section of the study, the relative importance of selected and partially comparable indicators is investigated in order to identify their associations with different levels of embeddedness of entrepreneurs in rural areas. This section of the study covers an explanation of our database created by the systematic collection of the results of existing applied studies while offering the application and the results of the RSDA.

\subsection{The database}

In order to form our database, an in-depth literature review was undertaken using many sources, i.e. web of science, the Internet, and other e-sources in order to locate studies on the embeddedness of rural entrepreneurs. The reviewed literature showed that there are two main types of embeddedness studies focusing on rural entrepreneurs, viz. (1) the embeddedness of enterprises usually from the agro-food sector in different markets; and (2) the embeddedness of rural entrepreneurs in the rural environment. However, although embeddedness is a matter of market networks, its dependency on social life in rural areas led us to focus on the second type of studies to better understand the situation of entrepreneurs in rural areas in terms of their being integrated in the community life.

After completing the preliminary study-gathering phase, we narrowed our study collection down by using the conceptual and theoretical framework of our study including the comparability of variables used in the studies. We had to eliminate some of the studies as they were not using common variables or were the same database used in other studies. For instance, two studies of Kalantaridis and Bika (2006a; 2006b) were both using the same database, so that the most suitable single paper from among these papers is included in our study. As a result, we came up with a limited number of studies, which led us to use the snowball technique by sending emails to the authors of the selected applied studies, asking if they had other or more forthcoming publications or reports. The use of the snowball technique provided us with a reasonable number of studies through which we generated our database 
for the application of RSDA. We used in total 16 applied studies published between 1997 and 2007 in order to create a systematic information table for RSDA (Table 1). Of these studies, only three are not journal articles. The main difference between the selected studies is their sample size which ranges from 2 to 513. Studies with a relatively larger sample size usually employed questionnaires, while the other studies used face-to-face interviews and qualitative ethnographic methods. From the 16 papers which evaluated different ELs, we retrieved each EL separately. This evaluation allowed us to retrieve a different number of distinct cases, so that in total we obtained a sample of 31 cases (see for overview Table 1).

Table 1. Papers used in the analysis

\begin{tabular}{|c|c|c|c|c|c|c|}
\hline ID & Author(s) name & $\begin{array}{c}\text { Year of } \\
\text { publication }\end{array}$ & $\begin{array}{c}\text { Type of } \\
\text { publication }\end{array}$ & Continent & $\begin{array}{l}\text { Sample } \\
\text { size }\end{array}$ & $\begin{array}{c}\text { Number of } \\
\text { cases } \\
\text { retrieved }\end{array}$ \\
\hline 1 & Smith S M et al. & 1997 & Journal & America & 118 & 1 \\
\hline 2 & Anderson A R (a) & 2000 & Journal & Europe & 2 & 1 \\
\hline 3 & Anderson A R (b) & 2000 & Journal & Europe & 14 & 2 \\
\hline 4 & Mankelow G and Merrilees B & 2001 & Journal & Oceania & 4 & 4 \\
\hline 5 & Jack S L and Anderson A R & 2002 & Journal & Europe & 7 & 3 \\
\hline 6 & Zontanos G and Anderson A R & 2004 & Journal & Europe & 2 & 1 \\
\hline 7 & Skuras D et al. & 2005 & Journal & Europe & 513 & 4 \\
\hline 8 & Psatopoulos D et al. & 2005 & Journal & Europe & 96 & 1 \\
\hline 9 & Anderson A R and McKain R & 2005 & Journal & Europe & 50 & 2 \\
\hline 10 & Kalantaridis $\mathrm{C}$ and Bika Z(b) & 2006 & Journal & Europe & 100 & 3 \\
\hline 11 & Zhang $\mathrm{J}$ et al. & 2006 & Journal & Asia & 486 & 1 \\
\hline 12 & Aitken K & 2006 & Report & Europe & 18 & 3 \\
\hline 13 & Siemens L & 2006 & Paper & America & 2 & 1 \\
\hline 14 & Weber S S & 2007 & Journal & America & 5 & 1 \\
\hline 15 & Stone I and Stubbs C & 2007 & Journal & Europe & 58 & 2 \\
\hline 16 & Gomez Velasco $\mathrm{M}$ and Saleilles $\mathrm{S}$ & 2007 & Paper & Europe & 4 & 1 \\
\hline
\end{tabular}

It ought to be recognized that the context and orientation of these studies may show quite some diversity (see also Stake, 2006), but the main aim of our study is to look for commonalities at a general conceptual - but nevertheless qualitatively measurable - level, while the focal point of comparing these different studies is embeddedness. Even though the aims of these studies were different, the integration and embeddedness of entrepreneurs in the local environment was evaluated and stated in association with the characteristics of entrepreneurs, including the nature of their business. On this basis, information gathered from the applied studies can be classified under two headings viz. (i) publication information (pub-info); and (ii) entrepreneurial information (entre-info) (see Table 2). Pub-info is used to evaluate in particular the statistical association of publication properties. In terms of pub-info, year of publication, year of data collection, sample size, and continent where the selected studies were undertaken are used. Among pub-info, sample size is the most important information, as studies can be precisely distinguished through this information. Year of data collection is another 
important type of information obtained from studies. Although the authors of ethnographic studies spend sometimes more than one year to collect data, we used only the last year of the data collection. Using the last year of data collection was because in-depth interviews of rural entrepreneurs were conducted during the last year of the study. On the other hand, although the studies were mainly undertaken in Europe, adding the region of the studies allowed us to see whether there is an impact of location characteristics on our results. At the end, we decided to use of continents instead of countries as location information, because some studies were undertaken in more than one country, so it was not possible to distinguish their information on the basis of country or region.

Table 2. Explanation of information retrieved from applied studies

\begin{tabular}{|c|c|c|}
\hline Name & Explanation & Category \\
\hline \multicolumn{3}{|l|}{ Publication information } \\
\hline A1. Year of Publication & Publication year of the selected study & Dummy: $1=$ published in and after $2005 ; 0=$ other \\
\hline A2. Year of data & $\begin{array}{l}\text { Last year of the data collection period of the } \\
\text { selected study }\end{array}$ & Dummy: $1=$ data collected in and after $2000 ; 0=$ other \\
\hline A3. Sample size & $\begin{array}{l}\text { Number of entrepreneurs in the sample of the } \\
\text { selected study }\end{array}$ & Dummy: $1=>9 ; 0=$ other \\
\hline A4. Continent & $\begin{array}{l}\text { Continent where the selected study was } \\
\text { undertaken }\end{array}$ & Dummy: $1=$ Europe; $0=$ other \\
\hline \multicolumn{3}{|c|}{ Entrepreneurial information } \\
\hline A5. Gender & $\begin{array}{l}\text { Percentage of females in the sample of the } \\
\text { selected study }\end{array}$ & Categorical: $1=0 \% ; 2=1-49 \% ; 3=50-99 \% ; 4=100 \%$ \\
\hline A6. Origin & $\begin{array}{l}\text { Percentage of in-migrants in the sample of the } \\
\text { selected study }\end{array}$ & Categorical: $1=0 \% ; 2=1-49 \% ; 3=50-99 \% ; 4=100 \%$ \\
\hline A7. Locality & $\begin{array}{l}\text { Percentage of local information usage of the } \\
\text { sample of the selected study }\end{array}$ & Categorical: $1=0 \% ; 2=1-49 \% ; 3=50-99 \% ; 4=100 \%$ \\
\hline A8. Externality & $\begin{array}{l}\text { Percentage of outside information usage of the } \\
\text { sample of the selected study }\end{array}$ & Categorical: $1=0 \% ; 2=1-49 \% ; 3=50-99 \% ; 4=100 \%$ \\
\hline A9. Sector of the firm & $\begin{array}{l}\text { Dominant sector of firms included in the sample } \\
\text { of the selected study }\end{array}$ & Categorical: $1=$ traditional; $2=$ tourism; $3=$ other \\
\hline D. EL & $\begin{array}{l}\text { EL of entrepreneurs described or defined in the } \\
\text { selected study }\end{array}$ & $\begin{array}{l}\text { Categorical: } 1=\text { disembedded; } 2=\text { underembedded } ; 3= \\
\text { embedded; } 4=\text { overembedded }\end{array}$ \\
\hline
\end{tabular}

In the selected studies, entrepreneurial information was of diverse types, and therefore, in order to obtain a common classification for the information retrieved from the studies, we used the mean percentage of the values. For instance, each entrepreneur included in the sample of the selected studies had different levels of local information usage, so, in the selected study, the mean usage is given as the percentage that we used for this value when forming our database. In the case of qualitative studies, sometimes indicators were given in the text by numbers, so we numerically calculated this kind of information in order to form our information table (Appendix 1). In addition, the EL of entrepreneurs was not always precisely given under the aforementioned categories of embeddedness, as defining and measuring embeddedness differ according to the perspective of the authors. Therefore, by means of the definition of embeddedness, the ELs of rural entrepreneurs were identified. In other words, we defined the decision attribute of cases on the basis of the embeddedness 
literature and the definition of different ELs. Fortunately, RSDA can be applied to any type of data, so it is able to handle effectively both quantitative and qualitative data if an information table can be obtained. In order to obtain such a table, we retrieved all available data from the selected studies, but we eliminated those data which were not related to our concept.

After obtaining the information table required for the RSDA application (Appendix 1), we categorized our data by using two types of data representation, i.e. dummy and categorical. Due to the concentration of publication data in specific years and continent, and the difficulty to categorise them, binary codification was used for pub-info (Table 2). On the other hand, entre-data is coded and evaluated as categorical data. Therefore, categorisation of the variables concerning percentages among selected studies are categorised into four categories through which we can identify the role of gender, origin, locality usage, and externality usage. In addition, in terms of the attribute referring to the sector (A9), two main sectors in the rural literature are differentiated among the studies viz., traditional sectors and tourism sector, while manufacturing, services and other sectors are taken into consideration as other sectors. Thus, we obtained a table called the coded value table. Section 3.2 applies now the RSDA, while Section 3.3 evaluates the results of the analysis.

\subsection{Embeddedness patterns of entrepreneurs: application of RSDA}

After obtaining the coded value table, RSDA can be performed. In order to perform RSDA, a modular software system Rough Set Data Explorer (ROSE) was used in order to implement basic elements of rough set theory and rule discovery techniques. This software was created at the Laboratory of Intelligent Decision Support Systems of the Institute of Computing Science in Poznan by Predki, Slowinski and Stefanowski in 1998 (Predki et al., 1998; Wu et al., 2004). There are also other attempts to create software for the application of RSDA, e.g. ROSETTA, but ROSE is the most user-friendly software to apply RSDA.

In the application of RSDA, three main steps based on rough set theory must be carried out, viz. pre-processing, attribute reduction, and rule induction. The first step is pre-processing. This step enables the researcher to see the quality of classification and the accuracy of each of the categories of the decision attribute by dividing the lower approximation by the upper approximation of each category. In other words, if quality and accuracy of classification is lower than 1 , then the chosen data and examples in the sample are not fully unambiguous concerning their allocation to the categories of 
decision attribute. This step strengthens the conclusions inferred on the basis of the other steps of the rough set analysis. Approximation of our rough sets shows that the sets of attributes and objects used in this analysis are elements of the 'universe'. This means by getting the highest score 1 in both accuracy and quality of classification, the objects used in this analysis can be generalized by applying the other steps of RSDA (Table 3). In other words, on the basis of the chosen indicators, the studies in our sample are fully discernible regarding the four dimensions of embeddedness.

Table 3. Approximations

\begin{tabular}{llrrr}
\hline Approximations & Accuracy & Upper level & Lower level \\
\hline $\mathbf{1}$ & Disembeddedness & 1 & 5 & 5 \\
$\mathbf{2}$ & Underembeddedness & 1 & 6 & 6 \\
$\mathbf{3}$ & Embeddedness & 1 & 13 & 13 \\
$\mathbf{4}$ & Overembeddedness & 1 & 7 & 7 \\
\hline Accuracy of classification & & & 1 \\
\hline Quality of classification & & & 1 \\
\hline
\end{tabular}

The second step of RSDA - the reduction - is used to form all combinations of condition attributes than can completely determine the variation in the decision attribute without needing another condition. In other words, in this step, minimal sets of attributes are found and these are called reducts. While finding reducts, RSDA can also find the frequency of appearance of all condition attributes in the reducts. If among them, one or more attributes has a frequency of $100 \%$, this is called the core. The reducts are given in Table 4. On the basis of the selected indicators, there are 3 sets of attributes which explain different levels of embeddedness. From Table 4, it can be seen that each set includes the locality level (A7), externality level (A8) and the sector (A9) which are called the core elements. The locality attribute is the most relevant indicator for the classification of different studies with the external relations and sector (Table 4). The relative importance of two types of pub-info, i.e. sample size (A3) and continent (A4) associated with the ELs of entrepreneurs show that publication characteristics have an impact on the determination of ELs.

Table 4. Frequency of attributes, reducts and core

\begin{tabular}{lrr}
\hline \multirow{2}{*}{ Attributes } & Frequency \\
& \multicolumn{2}{c}{$\%$} \\
\hline A7: Locality & 3 & 100.00 \\
A8: Externality & 3 & 100.00 \\
A9: Sector & 3 & 100.00 \\
A5: Gender & 1 & 33.33 \\
A4: Continent & 1 & 33.33 \\
A3: Sample size & 1 & 33.33 \\
\hline Reducts: $\{$ A3, A7, A8, A9\}; $\{$ A4, A7, A8, A9\}; $\{$ A5, A7, A8, A9\} & & \\
\hline Core: A7, A8, A9 & \multicolumn{3}{l}{} \\
\hline
\end{tabular}


The third and last step is rule induction. This provides rules which explain both the exact and the approximate relations between the decision and the condition attributes. An exact rule guarantees that the values of the decision attributes correspond to the same values of the condition attributes. Therefore, only in this case is it always possible to state with certainty whether or not, an object belongs to a certain class of the decision attribute. In addition, if a rule is supported by more objects, then it is more important, for instance, in summarizing the different single study results. In our RSDA application, 11 exact rules are generated. Among these 11 rules, 8 rules are supported by more than one case, while three rules are supported by only one single example having such a low strength that we excluded them from our decision rules list (Table 5). According to the related decision rules, each EL of entrepreneurs is explained by at least two exact rules.

Table 5. List of decision rules and their strengths of RSDA

\begin{tabular}{|c|c|c|c|c|}
\hline \multirow[t]{2}{*}{ Rules } & & & \multicolumn{2}{|c|}{ Strength } \\
\hline & & & \# & $\%$ \\
\hline Rule 1. $(\mathrm{A} 7=2) \&(\mathrm{~A} 8=3) \&(\mathrm{~A} 9=3) \&(\mathrm{~A} 4=1)$ & $\Rightarrow$ & $(\mathrm{D}=1)$ & 3 & 60.00 \\
\hline Rule 2. $(\mathrm{A} 8=4) \&(\mathrm{~A} 3=0)$ & $\Rightarrow$ & $(\mathrm{D}=1)$ & 2 & 40.00 \\
\hline Rule 3. $(A 7=2) \&(A 9=2)$ & $\Rightarrow$ & $(\mathrm{D}=2)$ & 2 & 33.33 \\
\hline Rule 4. $(A 7=1) \&(A 8=1)$ & $\Rightarrow$ & $(\mathrm{D}=2)$ & 2 & 33.33 \\
\hline Rule 5. $(\mathrm{A} 7=4) \&(\mathrm{~A} 8=1)$ & $\Rightarrow$ & $(\mathrm{D}=3)$ & 8 & 61.54 \\
\hline Rule 6. $(\mathrm{A} 7=3) \&(\mathrm{~A} 8=2)$ & $\Rightarrow$ & $(\mathrm{D}=3)$ & 5 & 38.46 \\
\hline Rule 7. $(A 7=4) \&(A 8=3)$ & $\Rightarrow$ & $(\mathrm{D}=4)$ & 3 & 42.86 \\
\hline Rule $8 .(\mathrm{A} 7=3) \&(\mathrm{~A} 8=3)$ & $\Rightarrow$ & $(\mathrm{D}=4)$ & 3 & 42.86 \\
\hline
\end{tabular}

The application of the RSDA shows that locality usage is the attribute most associated with the embeddedness level of entrepreneurs in rural areas as well as it is in terms of defining decision rules. According to the results of RSDA analysis, the decision rules for each level of embeddedness will now be evaluated in the following subsection.

\subsection{Empirical results}

The relations of the selected indicators and the levels of embeddedness, i.e. the decision rules, are summarized in Table 6, which refers to data obtained through two types of information, viz. pub-info and entre-info. Among these two types of information, the continent and the sample size of the studies are associated separately with the disembeddedness level, while no pub-info is associated with the other types of EL. The rules reflecting these relations can be seen as exact rules by means of which we were able to generate new hypotheses about the association between the variables used and the EL of rural entrepreneurs. 
Table 6. Results of the analysis

\begin{tabular}{|c|c|c|c|c|c|c|}
\hline Locality: & & Externality: & & Sector: & & Other: \\
\hline $1-49 \%$ & + & $\begin{array}{c}50-99 \% \\
100 \%\end{array}$ & + & other & $\begin{array}{l}+ \\
+\end{array}$ & $\begin{array}{l}\text { Continent: Europe } \\
\text { Sample size: } 1-9\end{array}$ \\
\hline $1-49 \%$ & 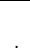 & $0 \%$ & + & tourism & & \\
\hline $100 \%$ & + & $0 \%$ & & & & \\
\hline $50-99 \%$ & + & $1-49 \%$ & & & & \\
\hline $\begin{array}{c}100 \% \\
50-99 \%\end{array}$ & $\begin{array}{l}+ \\
+\end{array}$ & $\begin{array}{l}50-99 \% \\
50-99 \%\end{array}$ & & & & \\
\hline
\end{tabular}

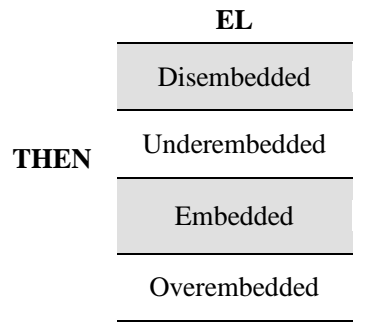

According to the first rule of disembeddedness, if studies are conducted in Europe on entrepreneurs who are not working in traditional sectors or tourism, and are using a high level of externality and a low level of locality in their work, then they are disembedded entrepreneurs. This rule explains the results of early studies focused on manufacturing or other industrial sectors which use rural areas as location of their firm without interacting with the rural environment. Such entrepreneurs usually do not know what happens in rural areas and do not interact strongly with rural inhabitants; thus, they do not prefer to be embedded. The second rule of disembeddedness is that if a study has a sample of less than 9 entrepreneurs - particularly in-depth ethnographic studies - who use purely external ties and resources, then they are disembedded. This again strengthens the previous rule. Thus, entrepreneurs who do not use features of locality in their business are grouped as disembedded.

According to the results related to underembeddedness, if entrepreneurs in the tourism sector do not use a high level of locality or if they do not use locality or externality resources in their business, then they can be grouped as underembedded. For instance, entrepreneurs in the tourism sector who run their business only using labour as locality resources without promoting other locality dynamics in their businesses, are underembedded. In addition, entrepreneurs who run their business on their own without any additional resources from local or external resources are also underembedded. If entrepreneurs do not make use of the local potential, they will not be able to break the defensive localism and will stay underembedded. Entrepreneurs at these levels of embeddedness are able to choose whether to increase their EL or to decrease it. The decision rules explaining the other levels of embeddedness are the composition of different levels of locality and externality usage of entrepreneurs. So, if an entrepreneur uses 100 percent locality without using any features of externality or if entrepreneurs use a high level of locality with less externality then they become embedded. On the other hand, if entrepreneurs use 100 percent locality or a high level of locality with a low level of 
externality, then they are overembedded. These rules completely reflect the current theory of embeddedness in rural areas.

Entrepreneurs having the two first levels, i.e. disembeddedness and underembeddedness, can be called 'disembedded entrepreneurs', while entrepreneurs having the other two ELs, i.e. embeddedness and overembeddedness, can be called 'embedded entrepreneurs'. According to the results of our analysis, in determining the EL of entrepreneurs, usage of locality and externality play an important role, although the disembeddedness of entrepreneurs depends also on the sector or publication characteristics, i.e. sample and location. Clearly, existing theories on embeddedness are reflected in our empirical results. It is also noteworthy that both the reducts and the decision rules show that among the characteristics of entrepreneurs, gender has a very low influence, while the origin of entrepreneurs has no influence at all in determining the ELs of entrepreneurs in rural areas.

\section{Conclusion}

The goal of achieving continuity and sustainability of rural areas calls for more involvement in the local area and for an increase of the use of local potential. The integration of entrepreneurs into rural areas has become one of the most important issues of rural development plans. However, the strong and closed social ties which have existed in rural areas for several decades make this integration a difficult task to achieve. Therefore, in the recent literature, the embeddedness of entrepreneurs has been discussed with reference to different assumptions and different theories. From this perspective, the aim of this study was to find out what matters most in order to become embedded in rural areas. To reach our aim, we combined the results of existing applied studies in order to evaluate the relations of different ELs of entrepreneurs and selected indicators on the basis of recently used theories.

The results of our analysis confirm most of the common assumptions on embeddedness related to the rural environment, while rejecting conventional urban theories transferred to the profiles of rural entrepreneurs. In the literature, not only using the potential of rural areas is important in achieving the goals of rural development plans, but also being able to benefit from this potential makes the start-up process of entrepreneurs easier and brings success faster than expected. The results of our study confirm this view and also show that using the locality is very important for an entrepreneur to be accepted in the rural environment. Another interesting outcome of our analysis is that the main theories of embeddedness based on urban evidence related to the profile of entrepreneurs seem to fail in the 
rural context. The results show that the origin of an entrepreneur does not influence nor does it have a great importance, in determining the EL of entrepreneurs. In addition, the results of our analysis stress the importance of the specific sector of the enterprise in order to determine the level of embeddedness of entrepreneurs. In the comparative approach used in this study, pub-data appeared to have a relative importance in terms of determining the EL, but, it was not as important as the locality level of entrepreneurs and the specific sector of enterprises.

The diversity of the studies in terms of sample size and the recent applications of many studies, including our own, obviously strengthen the need to develop rural-specific theories rather than use previously developed urban-specific theories. In the rural literature, there appears to be a lack of general studies and rural-specific treatments, and therefore independent case studies can only give insights about a limited amount of information, depending on the perception of researchers and entrepreneurs interviewed. Rural cannot be thought as completely independent from urban, but its specific characteristics call for an adjusted conceptualization in its theory. A generalization of rural development studies may then be possible.

In addition, not only in theory but also in policy arenas, rural areas need special treatment. A first treatment emerging from our results could be restructuring the collection of national data. A specific focus on rural areas concerning new trends would facilitate the understanding of the current rural situation and create relevant and tailor-made policies. It would also help in conducting large sample studies. Another policy lesson is related to the specific sector of the enterprises established in rural areas. Policy makers need to evaluate sector policies carefully, and they need to avoid giving support to economic activities which do not include using rural resources in their process.

The specific foci of early research on rural entrepreneurship cover only a limited amount of information. A comparative investigation of different entrepreneurial profiles including demographic and environmental changes that are occurring in diverse rural areas is lacking in the rural literature. Against the background of this study, more comparative in-depth research on the profiles of entrepreneurs is warranted. Therefore, the specific effects of the origin and gender of rural entrepreneurship should be investigated in greater detail. On this basis, research for rural studies in order to obtain rural-specific theories needs to be based more on comparative empirical evaluations rather than on specific groups. In this way, an operational extension and generalization of rural studies can most likely be achieved. 


\section{References}

Aitken, K. (2006) Young Entrepreneurs in Rural Northumberland and County Durham. Centre for Rural Economy, New Castle upon Tyne.

Anderson, A. and McKain, R. (2005) Rural entrepreneurship: perspectives of values in the rural environment, Journal of Rural Research and Policy, 12(4), 71-83.

Anderson, A. R. (2000a) Paradox in the periphery: an entrepreneurial reconstruction?, Entrepreneurship and Regional Development, 12(2), 91-109.

Anderson, A. R. (2000b) The protean entrepreneur: the entrepreneurial process as fitting self and circumstance, Journal of Enterprising Culture, 8(3), 201-234.

Bateman, D. and Ray, C. (1994) Farm Pluriactivity and Rural Policy: Some Evidence from Wales, Journal of Rural Studies, 10 (1), 1-13.

Camagni, R. (1991) Innovation Networks: Spatial Perspectives, John Wiley and Sons Ltd, London.

Clout, H. D. (1993) European Experience of Rural Development, Rural Development Commission, London.

Coffey, W. J. and Polèse, M. (1984) The concept of local development: a stages model of endogenous regional growth, Papers in Regional Science, 55 (1), 1-12.

Dacin, M. T., Ventresca, M. J., and Beal, B. D. (1999) The Embeddedness of Organizations: Dialogue \& Directions, Journal of Management, 25 (3), 317-356.

Flora, C. B., Flora, J., Spears, J., and Swanson, L. (1992) Rural Communities: Legacy and Change. Westview Press, Oxford.

Floysand, A. and Sjoholt, P. (2007) Rural Development and Embeddedness: The Importance of Human Relations for Industrial Restructuring in Rural Areas, Sociologia Ruralis, 47 (3), 205-227.

Francis, C. A., Flora, C. B., and King, L. D. (1990) Sustainable Agriculture in Temperate Zones. John Wiley \& Sons, London.

Frazier, B. J. and Niehm, L. S. (2004) Exploring business information networks of small retailers in rural communities, Journal of Developmental Entrepreneurship, 9 (1), $23-42$.

Gomez-Velasco, M. and Saleilles, S. S. (2007) The Local Embeddedness of Lifestyle Entrepreneur: an Explorative Study, in IECER Conference.

Granovetter, M. (1985) Economic action and social structure: the problem of embeddedness, American Journal of Sociology, 91 (3), 481-510.

Hinrichs, C. C. (2000) Embeddedness and local food systems: notes on two types of direct agricultural market, Journal of Rural Studies, 16(3), 295-303.

Ilbery, B. (1998) The geography of rural change, Longman, London.

Ilbery, B., Healey, M., Higginbottom, J., and Noon, D. (1996) Agricultural adjustment and business diversification by farm households, Geography, 81 (4), 301-310.

Jack, S. L. and Anderson, A. R. (2002) The effects of embeddedness on the entrepreneurial process, Journal of Business Venturing, 17 (5), 467-487.

Kalantaridis, C. and Bika, Z. (2006a) In-migrant entrepreneurship in rural England: beyond local embeddedness, Entrepreneurship and Regional Development, 18 (2), 109-131.

Kalantaridis, C. and Bika, Z. (2006b) Local embeddedness and rural entrepreneurship: case-study evidence from Cumbria, England, Environment and Planning A, 38 (8), 1561-1579.

Keeble, D. and Tyler, P. (1995) Enterprising Behaviour and the Urban-Rural Shift, Urban Studies, 32 (6), 975-997.

Kinsley, M. J. (1997) Economic Renewal Guide: A Collaborative Process for Sustainable Community Development, Rocky Mountain Institute, Colorado.

Kloosterman, R., van der Leun, J., and Rath, J. (1999) Mixed Embeddedness: (In)formal Economic Activities and Immigrant Businesses in the Netherlands, International Journal of Urban and Regional Research, 23 (2), 252-266.

Mankelow, G. and Merrilees, B. (2001) "Towards a model of entrepreneurial marketing for rural women: a case study approach", Journal of Development Entrepreneurship, vol. 6, no. 3, pp. 221 235.

Marsden, T. (1996) Rural geography trend report: the social and political bases of rural restructuring, Progress in Human Geography, 20 (2), 246-258.

Miller, N. L. and Besser, T. L. (2000) The importance of community values in small business strategy formation: evidence from rural Iowa, Journal of Small Business Management, 38 (1), 68-85.

Murdoch, J., Marsden, T., and Banks, J. (2000) Quality, Nature, and Embeddedness: Some Theoretical Considerations in the Context of the Food Sector, Economic Geography, 76 (2), 107-125.

Nijkamp, P. and Rietveld, P. (1999) Classification techniques in quantitative comparative research: a meta-comparison, Research Memorandum, Vrije Universiteit, Amsterdam. 
Pawlak, Z. (1991) Rough Sets: Theoretical Aspects of Reasoning about Data. Kluwer Academic Publishers, Dordrecht.

Penker, M. (2006) Mapping and measuring the ecological embeddedness of food supply chains, Geoforum, 37 (3), 368-379.

Petrin, T. and Gannon, A. (1991) Rural development through entrepreneurship. FAO, Rome.

Polanyi, K. (1944) The great transformation: Economic and political origins of our time, Rinehart, New York.

Predki, B., Slowinski, R., Stefanowski, J., Susmaga, R., and Wilk, S. (1998) ROSE: Software Implementation of the Rough Set Theory, Rough Sets and Current Trends in Computing, Lecture Notes in Artificial Intelligence, 1424, 605-608.

Psaltopoulos, D., Stathopoulou, S., and Skuras, D. (2005) "The Location of Markets, Perceived Entrepreneurial Risk, and Start-up Capital of Micro Rural Firms", Small Business Economics, vol. 25, no. 2, pp. 147-158.

Renzulli, L. A., Aldrich, H., and Moody, J. (2000) Family Matters: Gender, Networks, and Entrepreneurial Outcomes, Social Forces, 79 (2), 523-546.

Roberts, S. (2002) Key Drivers of Economic Development and Inclusion in Rural Areas, Initial scoping study for the socio-economic evidence base for DEFRA. DEFRA, London.

Romanelli, E. and Schoonhoven, C. B. (2000) The local origins of new firms. In The Entrepreneurship Dynamic: Origins of Entrepreneurship and the Evolution of Industries, Romanelli, E. and Schoonhoven, C. B. (eds)., 40-67. Stanford University Press, Stanford.

Schumpeter, J. A. (1934) The Theory of Economic Development, translated by R. Opie. Harvard Univeristy Press, Cambridge, MA.

Schumpeter, J. A. (1950) Capitalism, Socialism and Democracy. Harper and Row, New York.

Siemens, L. (2006) Operational Challenges of Rural/Remote Businesses: An Exploratory Study On Vancouver Island. In Reaching New Heights, H. Kelley, (ed.), Association des science administrative du Canada, Calgary.

Skuras, D., Meccheri, N., Moreira, M. B., Rosell, J., and Stathopoulou, S. (2005) Business Growth and Development Trajectories in Lagging and Remote Areas of Southern Europe, European Urban and Regional Studies, 12 (4), 335.

Slowinski, R. (1992) Intelligent Decision Support: Handbook of Applications and Advances of the Rough Sets Theory. Kluwer Academic Publishers, Dordrecht.

Smith, S. M., Findeis, J. L., Kraybill, D. B., \& Nolt, S. M. (1997) Nonagricultural micro-enterprise development among the Pennsylvania Amish: A new phenomenon, Journal of Rural Studies, 13(3), 237-251.

Sonnino, R. (2007) Embeddedness in action: Saffron and the making of the local in southern Tuscany, Agriculture and Human Values, 24 (1), 61-74.

Stake, R.E. (2006) Multiple Case Study Analysis, Guildford Press, New York.

Stathopoulou, S., Psatopoulos, D., and Skuras, D. (2004) Rural entrepreneurship in Europe, International Journal of Entrepreneurial Behaviour and Research, 10 (6), 404-425.

Stone, I. A. and Stubbs, C. (2007) Enterprising expatriates: lifestyle migration and entrepreneurship in rural southern Europe, Entrepreneurship \& Regional Development, 19 (5), 433-450.

Uzzi, B. (1997) Social Structure and Competition in Interfirm Networks: The Paradox of Embeddedness, Administrative Science Quarterly, 42 (1), 35-67.

Uzzi, B. (1999) Social Embeddedness in the Creation of Financial Capital, American Sociological Review, 64, 481-505.

van den Bergh, J. C. J. M., Button, K., Nijkamp, P., and Pepping, G. (1997) Meta-analysis in environmental economics. Kluwer Academic Publishers, Dordrecht

van der Ploeg, J. D. and Saccomandi, V. (1995) On the Impact of Endogenous Development in Agriculture. In Beyond Modernization: The Impact of Endogenous Rural Development, van der Ploeg, J. D. and van Dijk, G. (eds). Uitgeverij Van Gorcum, Assen.

van Leeuwen, E. S. and Nijkamp, P. (2006) The Embeddedness of Small Enterprises within the Rural Local Economy of Small and Medium Sized Towns. In The New European Rurality: Strategies for Small Firms, de Noronha Vaz, T., Morgan, E. J., and Nijkamp, P. (eds). Ashgate Publishing, Ltd., Aldershot.

Weber, S. S. (2007) Saving St. James: A case study of farmwomen entrepreneurs, Agriculture and Human Values, 24 (4), 425-434.

Whiteman, G. and Cooper, W. H. (2000) Ecological Embeddedness, The Academy of Management Journal, 43 (6), 1265-1282.

Whittington, R. (1992) Putting Giddens into Action: Social Systems and Managerial Agency, Journal of Management Studies, 29 (6), 693-712. 
Winter, M. (2003) Embeddedness, the new food economy and defensive localism, Journal of Rural Studies, 19 (1), 23-32.

Wortman, Jr. M. S. (1990) Rural Entrepreneurship Research: An Integration into the Entrepreneurship Field, Agribusiness, 6 (4), 329-344.

Wu, C., Yue, Y., Li, M., and Adjei, O. (2004) The rough set theory and applications, Engineering Computations, 21 (5), 488-511.

Zhang, J., Zhang, L., Rozelle, S., and Boucher, S. (2006) Self-Employment with Chinese Characteristics: The Forgotten Engine of Rural China's Growth, Contemporary Economic Policy, 24 (3), 446-458.

Zontanos, G. and Anderson, A. R. (2004) The nurturing and harvesting of a rural Greek network, International Journal of Entrepreneurial Behaviour and Research, 10(4), 260-276. 
Appendix 1. Information table

\begin{tabular}{|c|c|c|c|c|c|c|c|c|c|c|}
\hline ID & $\begin{array}{c}\text { A1: } \\
\text { Year of } \\
\text { publication }\end{array}$ & $\begin{array}{c}\text { A2: } \\
\text { Year of } \\
\text { data }\end{array}$ & $\begin{array}{c}\text { A3: } \\
\text { Sample } \\
\text { size }\end{array}$ & $\begin{array}{c}\text { A4: } \\
\text { Continent }\end{array}$ & $\begin{array}{c}\text { A5: } \\
\text { Gender }\end{array}$ & $\begin{array}{c}\text { A6: } \\
\text { Origin }\end{array}$ & $\begin{array}{c}\text { A7: } \\
\text { Locality }\end{array}$ & $\begin{array}{c}\text { A8: } \\
\text { Externality }\end{array}$ & $\begin{array}{c}\text { A9: } \\
\text { Sector }\end{array}$ & $\begin{array}{l}\text { D: } \\
\text { EL }\end{array}$ \\
\hline $01 \mathrm{~A}$ & 1997 & 1993 & 118 & Other & 81 & 0 & 92.7 & 35.4 & other & 3 \\
\hline 02A & 2000 & 1995 & 2 & Europe & 0 & 100 & 100 & 0 & tourism & 3 \\
\hline $03 \mathrm{~A}$ & 2000 & 1995 & 8 & Europe & 50 & 100 & 50 & 87.5 & other & 4 \\
\hline 03B & 2000 & 1995 & 6 & Europe & 0 & 0 & 66 & 17 & other & 3 \\
\hline 04A & 2001 & 2000 & 1 & Other & 100 & 100 & 100 & 0 & other & 3 \\
\hline 04B & 2001 & 2000 & 1 & Other & 100 & 100 & 0 & 0 & other & 2 \\
\hline $04 \mathrm{C}$ & 2001 & 2000 & 1 & Other & 100 & 100 & 50 & 50 & other & 4 \\
\hline 04D & 2001 & 2000 & 1 & Other & 100 & 0 & 100 & 50 & other & 4 \\
\hline $05 \mathrm{~A}$ & 2002 & 2001 & 1 & Europe & 100 & 100 & 100 & 0 & other & 3 \\
\hline $05 \mathrm{~B}$ & 2002 & 2001 & 1 & Europe & 0 & 100 & 0 & 0 & tourism & 2 \\
\hline $05 \mathrm{C}$ & 2002 & 2001 & 5 & Europe & 40 & 60 & 100 & 80 & other & 4 \\
\hline $06 \mathrm{~A}$ & 2004 & 1999 & 2 & Europe & 0 & 50 & 100 & 0 & traditional & 3 \\
\hline 07A & 2005 & 2000 & 127 & Europe & 20 & 52 & 88.8 & 8.39 & tourism & 3 \\
\hline 07B & 2005 & 2000 & 215 & Europe & 20 & 52 & 12.49 & 10.33 & tourism & 2 \\
\hline $07 \mathrm{C}$ & 2005 & 2000 & 58 & Europe & 20 & 52 & 88.36 & 84.24 & tourism & 4 \\
\hline 07D & 2005 & 2000 & 113 & Europe & 20 & 52 & 16.81 & 90.3 & other & 1 \\
\hline 08A & 2005 & 1999 & 96 & Europe & NA & 65.6 & 54.6 & 40.7 & other & 3 \\
\hline 09A & 2006 & 2001 & 56 & Europe & 48 & 30 & 62.9 & 40 & traditional & 3 \\
\hline 09B & 2006 & 2001 & 20 & Europe & 55 & 100 & 39.2 & 64.4 & other & 1 \\
\hline $09 \mathrm{C}$ & 2006 & 2001 & 24 & Europe & 20 & 80 & 35.5 & 55.6 & other & 1 \\
\hline $10 \mathrm{~A}$ & 2006 & 2000 & 16 & Europe & 31.25 & 0 & 100 & 0 & other & 3 \\
\hline $10 \mathrm{~B}$ & 2006 & 2000 & 34 & Europe & 38.23 & 100 & 50 & 100 & other & 4 \\
\hline $11 \mathrm{~A}$ & 2006 & 2000 & 486 & Other & 38 & 0 & 100 & 0 & other & 3 \\
\hline $12 \mathrm{~A}$ & 2006 & 2003 & 5 & Europe & 40 & 0 & 100 & 0 & traditional & 3 \\
\hline $12 \mathrm{~B}$ & 2006 & 2003 & 7 & Europe & 43 & 15 & less & 0 & other & 2 \\
\hline $12 \mathrm{C}$ & 2006 & 2003 & 6 & Europe & 50 & 100 & very low & 100 & other & 1 \\
\hline $13 \mathrm{~A}$ & 2006 & 2005 & 2 & Other & 0 & 50 & $<50$ & over 50 & other & 2 \\
\hline $14 \mathrm{~A}$ & 2006 & 2002 & 5 & Other & 100 & 100 & 100 & 0 & traditional & 3 \\
\hline $15 \mathrm{~A}$ & 2007 & 2005 & 27 & Europe & $>50$ & 100 & 100 & 60 & tourism & 4 \\
\hline $15 B$ & 2007 & 2005 & 31 & Europe & $>50$ & 100 & 39 & 83 & tourism & 2 \\
\hline $16 \mathrm{~A}$ & 2007 & 2005 & 4 & Other & 25 & 100 & 0 & 100 & other & 1 \\
\hline
\end{tabular}

